УДК 343.2

\title{
ІСТОРИЧНІ ТА ФІЛОСОФСЬКІ ЗАСАДИ СТАНОВЛЕННЯ ТА РОЗВИТКУ ПРИНЦИПУ ЗАКОННОСТІ В КРИМІНАЛЬНОМУ ПРАВІ
}

\author{
П. Демчук \\ Львівський національний університет імені Івана Франка, \\ вул. Університетська, 1, Львів, Украӥна, 79000, \\ e-mail: pavlo.demchuk@gmail.com
}

Розкрито погляд на основні віхи розвитку законності в кримінальному праві з огляду на історичні джерела, праці філософрів та правників у різні етапи розвитку правової думки. Особливу увагу приділено аналізу впливу позицій фрілософів епохи Просвітництва на становлення сучасного розуміння законності у кримінальному праві. Виявлено, що латинська максима «nulla poena nullum crimen sine lege», хоча і мала початки свого розвитку в римському праві, але наповнилася змістом, який і в сучасні часи визнається таким після Французької революції 1789 року. Одним із перших актів, який закріпив положення, що подібне до сучасного розуміння законності в кримінальному праві $€$ Французька Декларація про права людини 1789 року та Кримінальне уложення королівства Баварії 1813 року, яке розроблялося під керівництвом Пауля Фейєрбаха. Праці фрілософрів епохи Просвітництва (Томас Гоббс, Шарль Монтеск'є, Франсуа Марі Вольтер, Чезаре Беккарія) про відносини держави (влади) та громадян, у яких послідовно обстоювали ідею необхідності обмеження свавільної влади суверена, необхідності прийняття справедливих кримінальних законів, положення яких будуть відомі та зрозумілі суспільству, посприяли нормативному закріпленню основних правил, що становлять зміст законності. Висвітлено основні цінності, що стали основою для сучасного розуміння законності у кримінальному праві - свобода та особиста автономія, демократія, поділ влади та верховенство права.

Ключові слова: верховенство права, обмеження влади, особиста свобода, свавілля.

DOI: http://dx.doi.org/10.30970/vla.2020.70.218

Вступ. Свавілля державної влади (суверена) у будь-яких випадках призводить до порушення прав людини та основоположних свобод. Історія знає чимало випадків, коли ці цінності зневажала держава, і значно менше випадків, коли ці цінності становили зміст та спрямованість діяльності держави. Чітка регламентація положень, які є підставою для притягнення особи до кримінальної відповідальності одне із найважливіших надбань філософів та правників, що було здобуте не за одне століття розвитку правової думки.

Повноцінне дослідження змісту будь-якого принципу не буде можливим без з'ясування передумов його виникнення, певних історичних етапів розвитку положень, які тією чи іншою мірою дотичні до сучасного розуміння законності, що коротко сформульовано у максимі «nulla poena nullum crimen sine lege». Звісно, стан розвитку суспільства, технологій, комунікацій справляють значний вплив на правозастосування, у тому числі кримінальне, зокрема, щодо недопустимості зворотної дії кримінального закону, що погіршує становище особи, необхідність прийняття чітких недвозначних кримінально-правових положень із дотриманням субстантивних та процедурних демократичних вимог. Однак аналіз сучасних кримінальних законів, а особливо рішень міжнародних юрисдикційних органів,

(C) Демчук П., 2020 
П. Демчук

ISSN 0136-8168. Вісник Львівського університету. Серія юридична. 2020. Випуск 70

спрямованих на захист прав людини та основоположних свобод (зокрема, Свропейського суду з прав людини) свідчить про те, що навіть у цей час непоодинокими $\epsilon$ порушення законності в царині кримінального права.

Постановка проблеми. У національній науці кримінального права чимало праць присвячено проблемам, що стосуються окремих інститутів цієї галузі, питанням кваліфікації окремих складів злочинів та пов'язаним із ними проблемам притягнення до кримінальної відповідальності. Дослідженню принципів кримінального права, як основоположних ідей, які знаходять свій вираз у правових положеннях, присвячена незначна кількість наукових досліджень. Таке ставлення до принципів кримінального права як до підвалин цієї галузі $\epsilon$ невиправданим. Принципи законності, рівності, справедливості, гуманізму як такі, що становлять зміст верховенства права (яке окреслюється не лише перерахованими принципами), повинні слугувати першочерговим орієнтиром як при здійсненні нормотворчої діяльності, так і при застосуванні законодавчих положень. Відверте нехтування засадничими положеннями кримінального права призводить до порушення прав та основоположних свобод людини, що є недопустимим у конституційній державі. Законність як складова частина принципу верховенства права ставить особливі вимоги як до змісту кримінального закону, так i до його застосування, що обумовлює iї загальнообов'язковість та необхідність дослідження у всіх аспектах, у тому числі історичні та філософські передумови розвитку законності.

Аналіз останніх досліджень і публікацій. Серед вітчизняних наукових студій поступово підвищується привабливість дослідження принципів кримінального права. У статті авторства О. О. Дудорова та М. В. Мазура порушено питання співвідношення принципів законності та верховенства права, зокрема, у контексті впливу Нюрнберзького трибуналу на погляди щодо формальної законності [7, c. 138]. М. І. Панов у контексті дослідження якості кримінального законодавства вказав, на необхідність дотримання вимог принципу правової визначеності при побудові кримінально-правових норм $[14$, с. $10,15,16]$. Послідовна позиція, що принцип верховенства права в кримінальному праві реалізується саме через законність простежується у численних працях С. І. Хилюк $[18$, с. 334, 336]. Також законності, у контексті інших принципів кримінального права, приділено увагу у наукових роботах таких учених, як Ю. С. Резнік [213], О. С. Олійник [12], С. Я. Лихова [10], О. В. Степаненко [15].

Постановка завдання. Для комплексного дослідження законності в кримінальному праві передусім належить 3'ясувати історичний розвиток уявлень про необхідність чіткої регламентації підстав та проявів кримінальної відповідальності в нормативних актах за допомогою аналізу історичних джерел. Охарактеризувавши праці філософів, які заклали підвалини для розвитку законності, що відповідають сучасним уявленням, можна виявити ті цінності та передумови, що спонукали до таких умовиводів.

Виклад основного матеріалу. Аналіз праць вітчизняних та зарубіжних науковців дає змогу зробити однозначний висновок, що проблема законності у кримінальному праві пов'язана з основним завданням цієї галузі права - визначати підстави кримінальної відповідальності та форми іiі реалізації. Аналіз первинних джерел права ускладнює розмову про чітке виокремлення таких підстав. Здебільшого, відповідальність наставала за волею вождя, жреця у тій формі, яку вони вважатимуть за потрібну або ж були сформульовані настільки абстрактно, що говорити про існування навіть підвалин якогось принципу буде важко. Наприклад, у другому законі Ур-Намму з кінця XXI століття до нашої ери було сформоване 

Гебріел Голвей (Gabriel Hallevy) уважає це правило вже зародком законності.

Більшість науковців сходяться на думці, що першими абстрактними правилами, які можуть послугувати основою для розвитку законності в кримінальному праві були закони Древнього Риму. Як відомо, 8 та 9 таблиці 3 ХII таблиць Юстиніана були присвячені саме визначенню злочинів та покарань. Окрім цього, існувало правило «Роena non irrogatur, nisi quae quaque lege vel quo alio jure specialiter huic delicto imposita es» (покарання не накладається, крім випадків, коли воно встановлене законом чи іншим владним органом), яке набуло подальшого розвитку в законах Сулли, який чітко передбачив, що покарання повинно визначатися законом. Щодо дії кримінального закону в часі - в римському кримінальному праві були сформульовані доволі однозначні правила: закон дивиться тільки вперед, він не діє в зворотному напрямку; закон діє на майбутнє, суддя розглядає минуле; новий закон за своєю дією повинен бути звернений у майбутнє, але не в минуле. Зворотна сила кримінального закону уже відома, але розглядається як винятковий захід, дуже рідкісний виняток [2, с. 115-116].

Минаючи увагою епоху Середньовіччя зі загальновідомих причин, звернемося до Великої хартії вольностей 1215 року, у якій було проголошено, що «жодна людина не може бути заарештованою, або ув'язненою, або позбавленою володіння, або оголошена поза законом, або вигнана, або будь-яким іншим чином знедолена, $\mathrm{i}$ ми не підемо на неї і не пошлемо на неї інакше, як за законним вироком рівних їй i за законом країни» [16, с. 202]. Вдаючись до історії цього документа, належить вказати, що він виник унаслідок опозиції баронського і рицарського класів проти свавілля монархів, зокрема, щодо застосування покарань. Це положення було покладено в основу аналогічної норми Петиції про право 1628 року.

На відміну від прогресивної Англії, в країнах континентальної Свропи таких законодавчих положень ще не існувало. До прикладу, в кодексі Прусії 1721 року містилася вказівка на те, що правопорушення, які не передбачені в територіальному кодексі або не передбачені імперським законом, повинні бути засуджені ех aequo et bono, за винятком тих, що підлягають королівському суду. Баварський кодекс 1751 року передбачав положення, що справи, які не передбачені кодексом, мають бути вирішені ex aequitate et analogia juris, a Австрійський кодекс 1769 року передбачав, що справи, невикладені в Кодексі, повинні вирішуватися відповідно до принципів, викладених у Кодексі [24, с. 168].

Визначним етапом у розвитку людиноцентричного сприйняття кримінального права стала епоха Просвітництва та зародження класичної школи кримінального права. Саме тоді набули поширення та подальшого розвитку положення про необхідність доведення до відома норм права, які визначатимуть, за які дії суди каратимуть (у працях Томаса Гоббса, зокрема, було наголошено, що судді не повинні собою підміняти суверена, останній приймає закон, а перші лише застосовують його положення) [3, с. 209, 211], тлумачення закону на користь громадянина, якщо йдеться про його майно, честь чи життя [19, с. 74], суддя не може навіть під приводом ревного служіння суспільному благу, збільшувати міру встановленого в законі покарання громадянину, який порушив цей закон [1, с. 36, 38, 41$].$

Джером Гол наголошує, що розвиток вищевказаних ідей у нормотворчій практиці держав континентальної Європи відбувся під впливом концепції «rule of law» на філософів того часу та успішним поєднанням із тенденцією до прийняття кодифікованих законів [24, с. 168]. У той час було прийнято Австрійський кодекс Йозефа II 1787 року (Constitutio criminalis Josefina 1787), який містив вимогу від 
суддів буквального застосування закону та забороняв тлумачити закон, що був неясним (§ 24) [20, с. 74], Французька Декларація про права людини та громадянина 1789 року, у статті 8 якої було передбачено, що закон повинен встановлювати лише суворо необхідні покарання; ніхто не може бути покараний інакше, як 3 огляду назакон, прийнятий i оприлюднений до вчинення правопорушення i належно застосований [22]. Вже не в континентальній Європі, а в країні англосаксонського права - Сполучених Штатах Америки, в розділі 9 Конституції 1787 року передбачено заборону прийняття законів ex post facto [21].

Окрему увагу належить звернути на вченого, який запропонував використання вислову «nulla poena nullum crimen sine lege», який більшість науковців називають формулою принципу законності у кримінальному праві - Пауля Ансельма Феєрбаха. У своїй праці «Підручник загального чинного у Німеччині кримінального права», що датується 1801 роком, він виклав позицію, що каральним законом (lex poenalis) в широкому значенні називається кожен закон, який належить до злочинів та покарань, а у вузькому - містить визначення чи точну вказівку на необхідність настання зла за порушення кожного з прав. Він наголосив на тому, що суддівський вирок є лише засобом для застосування карального закону. Щоб він був правомірним, він має бути прийнятий на законних підставах, якими $є$ : можливість звільнення особи, лише у випадках, коли закон передбачає таке звільнення; можливість засудження особи, лише у випадках, коли каральний закон iii засуджує [17, с. 72-75]. Саме такі положення були викладені у Баварському кодексі, який писався під керівництвом Фейєрбаха у 1813 році. Він справив величезний вплив на розвиток кримінального законодавства не лише у Німеччині, а й в інших країнах, зокрема, Російській імперії.

Ідеї обмеження влади, просування поваги до природних прав людини, розвиток концепцій, що права не даровані державою, а належать людині від природи, що вимагає дотримання цих прав не лише іншими людьми, а й державою, сприяли підвищенню ролі ідей особистої свободи та індивідуалізму, автономії в правотворенні. У контексті дослідження законності в кримінальному праві ці цінності мають одне 3 найважливіших значень, починаючи від того, що кримінальнокараною може визнаватися лише вольова поведінка особи, і закінчуючи тим, що для адекватного прийняття рішень та здійснення вільного вибору кожна особа повинна знати, які іiї дії будуть законними, а які протиправними.

Такі позиції будувалися, зокрема, на таких філософських міркуваннях. Автономія людини полягає в свободі вибору, індивіди $є$ вільними від зовнішніх обмежень, таких як примус, насильство, різні форми погроз та маніпуляцій; дії $\epsilon$ наслідком їх вибору [4, с. 447]; свобода поділяється на позитивну (власне бажання людини самостійно визначати свою долю, не керуватися вказівками інших людей) та негативну (відсутність перешкод та втручань в особисту сферу кожного) [27, c. 120]; дотримання жорстких правил сприяє утриманню людських істот від порушення прав інших, обмеження щодо дій особи повинні бути встановлені чіткими юридичними постановами $[11$, с. 88$]$; підставою для позбавлення людини свободи може бути лише вільна поведінка людини, а не примус чи інші випадки, які виключають наявність волі [6, с. 30].

До цінностей, які визначають засаду законності у кримінальному праві також відносять демократію як спосіб прийняття владних рішень, у тому числі тих, які визначатимуть перелік кримінально-караних діянь та відповідальність за їх вчинення. Вказана позиція є важливою 3 тих підстав, що демократичний спосіб прийняття кримінальних законів узгоджуватиметься 3 концепцією добровільного 
покладення населенням певної держави на себе певних обмежень щодо поведінки та, відповідно, згоду на настання несприятливих наслідків у випадку порушення цих обмежень. Це та підвалина, якої не існувало в часи, коли кримінально-правові норми формувалися звичаями, королями без участі парламенту та в інші недемократичні способи.

Максимальна можливість реалізувати свободу самовизначення, тобто жити за законами, які особистість обирає для себе самостійно, є основною перевагою демократії. Процес прийняття законів повинен скеровуватися такими критеріями: перед прийняттям рішення буде забезпечена можливість висловити свою думку про нього; буде гарантована можливість обговорення, пошуку компромісів, переговорів, що допоможе прийняти рішення, оптимальне для всіх членів суспільства; якщо одностайної думки достягнути не вдасться, в результаті буде прийнятий закон, що отримав прихильність максимальної кількості членів суспільства [5, с. 56].

Такі критерії особливо важливі при прийнятті кримінальних законів, оскільки будь-яке необгрунтоване рішення законодавця призводитиме до порушення прав людини в найгрубшій формі, адже кримінально-правові засоби чинять найбільш суворий вплив на особисту свободу та автономію людини.

Водночас, не потрібно зводити дотримання демократичних процедур та правил до надмірної формальності. Існують також внутрішні обмеження демократії. Такий підхід до демократії називається субстантивним і він полягає в тому, що рішення вважається прийнятим у демократичний спосіб не лише за дотримання демократичних процедур, а й тоді, коли це рішення прийняте із засад поваги до людської гідності [29, с. 46-47].

Розвиток учень про демократію був би неможливим без розвитку та запровадження напрацювань на практиці про поділ влад, за якого реалізується система стримувань і противаг, яка покликана запобігати авторизації влади в руках однієї з їі гілок. На важливості розмежування повноважень законодавчої та судової гілок влади у сфері кримінальної юстиції акцентували увагу Ч. Беккаріа, П. Фейєрбаха та інші філософи (правники), адже саме вони розвинули думку про обмежену роль судді в застосуванні кримінального закону. Дійсно, творення кримінально-правових норм судовою гілкою влади зневажає одразу декілька цінностей, які становлять основу законності можливість особи передбачати наслідки своєї поведінки, шляхом сприйняття завчасно опублікованих нормативних актів; обгрунтованість та широке обговорення нормативних актів, що встановлюють кримінальну відповідальність особи.

Серед дослідників законності в кримінальному праві в англосаксонській системі права, висловлено думку, що суди не можуть довільно створювати кримінальноправові норми, тому для встановлення балансу між справедливістю та законністю випрацювано спеціальні критерії [26, с. 240]. У межах континентальної системи права, не зважаючи на широку підтримку позитивістських ідей, повне уникнення суддівської дискреції $є$ неможливим, оскільки варіації життєвих обставин $\epsilon$ невичерпними і таке завдання буде свідомо недосяжним.

Верховенство права, за формальним підходом, полягає, в своїй основі, у вимозі урядовцям та громадянам бути «зв'язаними» та діяти відповідно до закону. Ця основна вимога зумовлює набір мінімальних характеристик: закон має бути викладений заздалегідь (бути перспективним), оприлюднюватися, бути загальним, бути чітким, бути стабільним та визначеним і застосовуватися однаково до всіх відповідно до його умов. За відсутності цих характеристик верховенство права не існує. Більш широкий підхід до верховенства права оперує також поняттями фундаментальних прав, демократії та/або критеріями справедливості чи права. У 
своїй публікації Б. Таманага наводить дві функції верховенства права - встановлювати правові обмеження на урядовців (у два способи - вимагаючи відповідності їхніх дій існуючим законам та встановлюючи правові обмеження розсуду нормотворчих повноважень) та підтримувати порядок і контролювати поведінку та взаємодію між громадянами (громадяни повинні дотримувати встановлених правом правил поведінки, їх недотримання матиме наслідком відповідні дії правоохоронних органів) [30, с. 3-6].

Виглядає, ніби вищеперелічені цінності, які становлять підвалини законності у кримінальному праві, охоплюють концепцію верховенства права. Таке співвідношення дає змогу тісно пов'язати вказані принципи та звернути увагу, що між цими принципами (поняттями) науковці встановлюють різні зв'язки, які роглянемо в інших публікаціях.

Не зважаючи на такий рівень розвитку філософської та правової думки, у XX столітті відбувалися події, які вплинули не лише на формування та активний розвиток міжнародного публічного права, а й на розвиток законності в кримінальному праві. Під час Другої світової війни активно постало питання притягнення до відповідальності військових злочинців країн осі «Берлін-Рим». Після палких дискусій між СРСР, США та Великою Британією було прийнято рішення, що німецькі воєнні злочинці, а також нацистські лідери і керівний склад нацистських установ і організацій мають бути арештовані й передані для швидкого й справедливого суду. Для цієї мети створили Міжнародний воєнний трибунал та Статут, який визначає, з-поміж процедурних питань, перелік складів злочинів, за вчинення яких притягатимуть до відповідальності військових злочинців.

Формулювання правових положень Статуту Міжнародного воєнного трибуналу, які визначали ознаки складів злочинів, за вчинення яких притягали військових злочинців, дозволяли захисникам обвинувачених висловлювати доводи, що вони не $\epsilon$ достатньо чіткими, щоб бути підставою для застосування, відтак, всі сумніви повинні тлумачитися на користь сторони захисту; існування заборони законів ех post facto; жодна суверенна держава не оголосила агресивну війну злочином у той час, коли були здійснені ці нібито злочинні дії, жоден статут не дав визначення агресивної війни, не було встановлено жодної кари за іiї ведення і не було створено жодного суду для переслідування та покарання порушників [23, с. 101].

Суд був поставлений у складну позицію - необхідність вирішення питання балансу між справедливістю та законністю. У цьому контексті доречно навести позицію Г. Радбруха, яка полягає в тому, що прагнення до справедливості повинно відбуватися через її складову частину - правову визначеність, а у випадку кричущого конфлікту між змістом законів (так званим, законним неправом) та справедливістю (так званому, надзаконному праву), перевага повинна надаватися останньому [8, с. 94]. Нюрнберзький трибунал обгрунтував свою позицію тим, що суд зв'язаний статутом про його створення та діяльність; встановлення злочинів у статуті про його створення та діяльність не порушувало принцип законності, оскільки це були прописані в ньому загальні положення та принципи звичаєвого міжнародного права, яке існувало на час вчинення агресії; принцип законності не є обов’язковим для суду [28].

Таке обгрунтування не сприймалося однозначно в правничих колах, однак правосуддя вже звершилося. Натомість така практика справила своє враження на формулювання текстуального викладу формули «nullum crimen nulla poena sine lege» в низці міжнародних декларацій та конвенцій. Йдеться, наприклад, про формулювання ч. 2 ст. 7 Конвенції про захист прав людини та основоположних свобод: «ця стаття не $\epsilon$ перешкодою для судового розгляду, а також для покарання 
будь-якої особи за будь-яку дію чи бездіяльність, яка на час ії вчинення становила кримінальне правопорушення відповідно до загальних принципів права, визнаних цивілізованими націями» [9].

Висновки. Про формування законності у кримінальному праві можна говорити, починаючи вже із римського кримінального права, у положеннях якого містилися заборони ретроспективного засудження, вимоги притягнення до кримінальної відповідальності лише на підставі закону і накладення покарання лише такого, яке визначено цим законом.

Передумовою для закріплення в нормативних актах правових положень, що обмежують свавілля суверена щодо накладення покарань, були зловживання останніх. Поступова боротьба між різними соціальними станами та узгодження компромісів щодо нормативного регулювання найважливіших питань суспільного життя посприяли розвитку ідей стосовно необхідності публікування карних законів, неможливості суддів свавільно застосовувати покарання. Ці праці позитивно вплинули на формування кримінальних законів країн Свропи у XVIII-XIX століттях.

Основними цінностями, які науковці слушно вважають такими, що становлять підвалини принципу законності, є особиста свобода та автономія, демократія, поділ влад та верховенство права. Щодо останнього, належить встановити зв'язок між законністю та верховенством права і їх способи реалізації в кримінальному праві.

Особиста свобода та автономія є запорукою для реалізації законності в кримінальному праві з огляду на те, що лише за умови вільного вибору своєї поведінки людина може повноцінно реалізовуватися як соціальна та біологічна істота, водночас, свою поведінку вона повинна узгоджувати зі загальноприйнятими правилами, щоб мати можливість передбачити наслідки своїх дій.

Демократичний процес прийняття рішень узгоджуватиметься 3 концепцією добровільного, а не примусового покладення на себе обмежень, що встановлюються державною владою, а також забезпечуватиме відкритий спосіб прийняття нормативних актів із належним обговоренням та можливістю розгляду різних пропозицій.

Поділ влад $\epsilon$ запорукою реалізації попередніх двох цінностей, адже за умови демократичного прийняття нормативного акту, який передбачає підстави настання кримінальної відповідальності та форми і засоби іiі реалізації, такий нормативний акт повинен обмежувально (а не поширювально) тлумачитися судом. У подальших дослідженнях детальніше з'ясовуватимемо правила тлумачення та застосування кримінального закону.

Одним із визначальних етапів розвитку законності у XX столітті була діяльність Міжнародного воєнного трибуналу, який підняв у сучасному суспільстві питання балансу формальної законності та справедливості і вказав, що у випадку, коли діяння $\epsilon$ явно несправедливим, тобто суперечить загальноприйнятим цінностям та нормам, існування закону чи іншої нормативної підстави для притягнення до кримінальної відповідальності не вимагається. Фактично, можна провести грубу аналогію 3 концепцією судового кримінального правотворення в англосаксонській системі права. Це питання цікаве у контексті наукового дослідження та може бути надалі опрацьоване.

Отже, законність у кримінальному праві $є$ складною категорією, яка має за свою основу засадничі цінності цивілізованого демократичного суспільства, що обумовлює важливість іiі застосування на всіх етапах реалізації кримінальноправових норм. Якість такого застосування неможливо забезпечити без з'ясування змісту правил, які становлять зміст законності у кримінальному праві, тому подальші наукові розробки у цьому напрямі будуть бажаними для поступу національної правової системи. 


\section{Список використаних джерел}

1. Беккариа Ч. О преступлениях и наказаниях / пер. с ит. Ю. М. Юмашева. Москва: Междунар. отношения, 2000. $240 \mathrm{c.}$

2. Бойко А. И. Римское и современное уголовное право. Санкт-Петербург: Издательство «Юридический центр Пресс», 2003. 259 с.

3. Гоббс Т. (1588-1679). Сочинения: в 2 т.: [пер. с лат. и англ.] / [сост., ред. и вступ. ст. В. В. Соколова]; АН СССР, Ин-т философии. Москва: Мысль, 1991. Т. 2. 736 с. ISBN 5-244-00020-9.

4. Грищук О. В. Автономія людини та людська гідність: філософсько-правові особливості взаємозв'язку // Науковий вісник Львівського державного університету внутрішніх справ. Серія юридична. 2013. Вип. 1. С. 447-455.

5. Даль Р. О демократии / пер. с англ. А. С. Богдановского; под ред. О. А. Алякринского. Москва: Аспект Пресс, 2000. 208 с.

6. Дворкин P. O правах всерьез / пер. с англ.; ред. Л. Б. Макеева. Москва: «Российская политическая энциклопедия» (РОССПЭН), 2004. 392 с.

7. Дудоров О. О., Мазур М. В. Реалізація принципу верховенства права при застосуванні закону про кримінальну відповідальність: постановка проблеми, міжнародний $\mathrm{i}$ зарубіжний досвід // Юридичний науковий електронний журнал. 2017. № 5. С. 129-140. Режим доступу: http://www.lsej.org.ua/5_2017/36.pdf.

8. Законне неправо та надзаконне право - автор Радбрух Густав: Gustav Radbruch. Gesetzliches Unrecht und Uebergesetzliches Recht // Проблеми філософії права. 2004. Т. II. C. 83-94.

9. Конвенція про захист прав людини і основоположних свобод: Конвенція від 04.11.1950 // База даних «Законодавство України» / ВР України. URL: https://zakon.rada.gov.ua/laws/show/995_004 (дата звернення 01.02.2020).

10. Лихова С. Я. Верховенство права Європейського Союзу як одна із причин реформування кримінального законодавства України // Новітні кримінально-правові дослідження - 2016: зб. наук. пр. / відп. ред. О. В. Козаченко. Миколаїв: Іліон, 2016. С. 40-43.

11. Міл Дж. С. Про свободу: Есе / пер. 3 англ. Київ: Видавництво Соломії Павличко "Основи", 2001. 463 с.

12. Олійник О.С. Ієрархія принципів кримінального права України // Правова позиція. 2019. Вип. 3 (24). С. 7-13.

13. Резнік Ю. С. Принцип гуманізму та його реалізація в кримінальному праві України [Текст]: автореф. дис.... канд. юрид. наук : 12.00.08 / НАН України, Ін-т держави і права ім. В. М. Корецького. Київ, 2017. 20 с.

14. Панов M. I. Принцип правової визначеності у практиці Європейського суду з прав людини і проблеми якості кримінального законодавства України // Проблеми законності. 2015. Вип. 128. С. 8-19.

15. Степаненко О.В. Принцип доцільності в кримінально-правовій доктрині та кримінальному законодавстві України: дис.... канд. юрид. наук: 12.00.08. Одеса, 2017. 249 с.

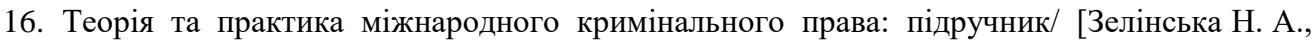
Андрейченко С. С., Дрьоміна-Волок Н. В., Коваль Д. О.; за ред. Проф. Зелінської Н. А.]. Одеса: Фенікс, 2017. 582 с.

17. Фейербах П. И. А. (1775-1833). Уголовное право [Текст] / Сочинение доктора Павла Анзельма Фейербаха. Санкт-Петербург: В Медицинской типографии, 1810-1827. 8; 21 см. Кн. 1. 1810.144 c.

18. Хилюк C. В. Nulla poena sine lege як складова принципу законності у практиці європейського суду 3 прав людини // Науковий вісник Львівського державного університету внутрішніх справ. Серія юридична. 2013. Вип. 2. С. 334-345. 
19. Монтескье Ш. Про дух законів. URL: http://www.civisbook.ru/files/File/Monteskye.O dukhe.pdf (дата звернення 08.01.2020 року).

20. Шаргородский М. Д. Избранные труды. Санкт-Петербург: Юрид. центр Пресс, 2004. $655 \mathrm{c}$.

21. Constitution of the United States. URL: https://www.senate.gov/civics/constitution_item/constitution.htm (дата звернення: 06.01.2020 року)

22. Déclaration des Droits de l'Homme et du Citoyen de 1789. URL: https://www.conseilconstitutionnel.fr/le-bloc-de-constitutionnalite/declaration-des-droits-de-l-homme-et-ducitoyen-de-1789 (дата звернення 06.01.2020 року)

23. Gallant K. The Principle of Legality in International and Comparative Criminal Law (Cambridge Studies in International and Comparative Law). Cambridge: Cambridge University Press, 2008. doi:10.1017/CBO9780511551826

24. Hall J. Nulla Poena Sine Lege. Articles by Maurer Faculty. Paper 1378. 1937/ URL: http://www.repository.law.indiana.edu/facpub/1378

25. Hallevy G. A Modern Treatise on the Principle of Legality in Criminal Law, 2010. 10.1007/978-3-642-13714-3

26. Horder J. Criminal law and legal positivism // Legal Theory. 2002. № 8. S. 221-241. $10.1017 / \mathrm{S} 1352325202082034$.

27. Isaiah Berlin, "TWO CONCEPTS OF LIBERTY" Four Essays On Liberty, (Oxford, England: Oxford University Press, 1969), P. 118-172. URL: http://cactus.dixie.edu/green/B_Readings/I_Berlin\%20Two\%20Concpets\%20of\%20Liberty.pdf

28. Judgment of 1 October 1946 - International Military Tribunal (Nuremberg). URL: https://crimeofaggression.info/documents/6/1946_Nuremberg_Judgement.pdf (дата звернення 01.02.2020).

29. Peristeridou $C$. Theoretical Rationales of the Legality Principle. In The principle of legality in European criminal law. 2015. P. 33-64. Intersentia. doi:10.1017/9781780685625.003.

30. Tamanaha Brian Z. A Concise Guide to the Rule of Law. FLORENCE WORKSHOP ON THE RULE OF LAW, Neil Walker, Gianluigi Palombella, eds., Hart Publishing Company, 2007; St. John's Legal Studies Research Paper No. 07-0082. Available at SSRN: https://ssrn.com/abstract=1012051.

\section{References}

1. Beccaria, C. B. di. (2000). O prestupleniyah i nakazaniyah / Y. M. Yumashev, Trans.). Moscow, Russia: Mezdunar. otnosh.

2. Boyko, A. (2003). Rimskoe i sovremennoe ugolovnoe pravo. Saint Petersburg, Russia: Yuridicheskiy tsentr-Press.

3. Hobbes, T. (1991). Sochineniya: v 2 t. (V. Sokolova, Ed.). Moscow, Russia: Myisl.

4. Hryshchuk, O. (2013). Human autonomy and dignity: philosophical and legal features of interrelation. Naukovyj Visnyk L'vivs'koho Derzhavnoho Universytetu Vnutrishnikh Sprav, 1, 447-455.

5. Dahl, R. (2000). On Democracy / A. Bogdanovskiy, Trans., O. Alyakrinskiy, Ed.). Moscow, Russia: Aspekt Press.

6. Dvorkin, R. (2004). O pravah vserez / L. Makeeva, Ed.. Moscow, Russia: Rossiyskaya politicheskaya entsiklopediya.

7. Dudorov, O. \& Mazur, M., (2017). Realization of The Rule of law principle in the application of the law on criminal liability: raising the issue, international and foreighn expirience. Yurydychnyj Naukovyj Elektronnyj Zhurnal, 5, 129-140.

8. Radbruch, G. (20n.d.). STATUTORY NON-LAW AND SUPRASTATUTORY LAW. (V. Bihun, Trans.). Problemy Folosofii Prava, 2, 83-94.

9. European Convention on Human Rights. (n.d.). Retrieved February 1, 2020, from https://zakon.rada.gov.ua/laws/show/995_004 
10. Likhova, S. (2016, May 20). Verkhovenstvo prava Yevropejs'koho Soiuzu iak odna iz prychyn reformuvannia kryminal'noho zakonodavstva Ukrainy. Retrieved from http://hdl.handle.net/11300/4857

11. Mill, J. S. (2001). Pro svobodu. (S. Pavlychko, Trans.). Kyiv, Ukraine: Osnovy.

12. Oliinyk, O. (2019). Hierarchy of the principles of criminal law of Ukraine. Pravova Pozytsiia, 3, 7-13. doi: 10.32836/2521-6473-2019-3-7-13

13. Reznik, Y (2017). Pryntsyp humanizmu ta joho realizatsiia v kryminal'nomu pravi Ukrainy: avtoreferat dysertatsii ; Instytut derzhavy i prava im. V. M. Korets'koho.

14. Panov, M. (2015). The principle of legal certainty in the practice of the European Court of Human Rights and the quality problems of the criminal legislation of Ukraine. Problemy Zakonnosti: Zb. Nauk. Pr, 128, 8-19.

15. Stepanenko, O. (2017). Pryntsyp dotsil'nosti $v$ kryminal'no-pravovij doktryni ta kryminal'nomu zakonodavstvi Ukrainy. Odesa.

16. Zelinska, N., Andreychenko, S., Deriomina-Volok, N., \& Koval, D. (2017). Teoriia ta praktyka mizhnarodnoho kryminal'noho prava: pidruchnyk. (N. Zelinska, Ed.). Odesa, Ukraine: Fenix.

17. Feuerbach, P. (1810). Ugolovnoe pravo. Saint Petersburg, Russia: V Meditsinskoy tipografii.

18. Khyliuk, S. (2013). Nulla poena sine lege as a part of the legality principle in the practice of the European Court of Human rights. NAUKOVYJ VISNYK L'vivs'koho Derzhavnoho Universytetu Vnutrishnikh Sprav, 2, 334-345.

19. Monteskye, S. (2010, November 27). O dukhe zakonov. Retrieved January 8, 2020, from https://www.civisbook.ru/files/File/Monteskye_O dukhe.pdf.

20. Shargorodskiy, M. (2004). Izbrannyie trudyi. Saint Petersburg, Russia: Yurid. tcentr. press.

21. Constitution of the United States. (2020, January 21). Retrieved from https://www.senate.gov/civics/constitution_item/constitution.htm

22. Déclaration des Droits de l'Homme et du Citoyen de 1789. (n.d.). Retrieved from https://www.conseil-constitutionnel.fr/le-bloc-de-constitutionnalite/declaration-des-droits-de1-homme-et-du-citoyen-de-1789

23. Gallant, K. (2008). The Principle of Legality in International and Comparative Criminal Law. Cambridge Studies in International and Comparative Law. Cambridge: Cambridge University Press. doi:10.1017/CBO9780511551826

24. Hall, Jerome. (1937). Nulla Poena Sine Lege. Articles by Maurer Faculty. Paper 1378. Retrieved from http://www.repository.law.indiana.edu/facpub/1378

25. Hallevy, Gabriel. (2010). A Modern Treatise on the Principle of Legality. In: Criminal Law. 10.1007/978-3-642-13714-3

26. Horder, Jeremy. (2002). Criminal law and legal positivism. Legal Theory. 8. 221-241. $10.1017 / \mathrm{S} 1352325202082034$.

27. Isaiah Berlin. (1969). TWO CONCEPTS OF LIBERTY. Four Essays On Liberty, (Oxford, England: Oxford University Press, 118-172. Retrieved from http://cactus.dixie.edu/green/B_Readings/I_Berlin\%20Two\%20Concpets\%20of\%20Liberty.pdf

28. Nuremberg Judgment against Major War Criminals. (2008, November 10). Retrieved February 15, 2020, from https://www.legal-tools.org/doc/45f18e/

29. Peristeridou, C. (2015). Theoretical Rationales of the Legality Principle. In: The principle of legality in European criminal law (p. 33-64). Intersentia. doi:10.1017/9781780685625.003.

30. Tamanaha, Brian Z. (2007). A Concise Guide to the Rule of Law. FLORENCE WORKSHOP ON THE RULE OF LAW, Neil Walker, Gianluigi Palombella, eds., Hart Publishing Company; St. John's Legal Studies Research Paper No. 07-0082. Available at SSRN: https://ssrn.com/abstract $=1012051$. 


\section{HISTORICAL AND PHILOSOPHICAL GROUNDS OF RAISING AND DEVELOPMENT OF LEGALITY IN CRIMINAL LAW}

\section{P. Demchuk}

Ivan Franko National University of Lviv,

1, Universytetska Str., Lviv, Ukraine, 79000, e-mail: pavlo.demchuk@gmail.com

The system of strong rules of imposing penalties is the main characteristic of the field of criminal law in modern democratic states. Incorrect implication of the criminal law provisions will directly affect human rights and freedoms. The issues of criminal law correspondence with the human rights concept and the rules of interpreting criminal law provisions are still actual even for the states with sustainable democratic development. All these problems are covered by legality in the rule of law concept.

Historical method is quite useful in legal research, especially in untangling legal problems, which have roots in the past. Raising and development of legality through centuries will help us to fully interpret values, which are the grounds of this principle.

In the XXI century B.C., the law on criminal liability contented one beautiful rule - "if you act illegally - we can kill you". Fortunately, criminal law provisions are changing through time. Arbitrariness of the sovereign, vague in the implication of penalty, uncertainty in the criminal law provisions - all these problems were the main engines for the liberal revolutions in the XVII century. As a result, modern nations have similar meaning of the legality in criminal law, as in the French Declaration of the Rights of Man and of the Citizen of 1789 or the Constitution of the United States of 1787.

Legality in criminal law consists of such main values as freedom and individual autonomy, democracy, separation of power as well as the rule of law. The works of philosophers in the Enlightenment era (such as Montesquieu, Hobbs, Feuerbach, Beccaria) have had a huge impact on the development of these values and can help us to find modern interpretation of the meaning of legality. This paper provides us with the reasoning, why the above values are important for understanding legality as the principle of criminal law.

Legality not only brings us protection from the unlawful legal provisions. There are examples in history, when the law allowed to commit atrocities. The decisions of International Military Tribunal at Nuremberg show us the way to resolving this dilemma and import us the general principles of law recognised by civilised nations as a ground for criminal liability.

Our results illustrate that the legality in criminal law is the scope of provisions, which establish special requirements to the lawmaking process (including the elements of substantive and procedural democracy), the process of interpreting the criminal law provisions as well as the process of applying the law in every individual case.

Keywords: rule of law, limitation of power, individual autonomy, arbitrariness of power. 